\title{
Maritime aerosol network as a component of AERONET - first results and comparison with global aerosol models and satellite retrievals
}

A. Smirnov ${ }^{1,2}$, B. N. Holben ${ }^{2}$, D. M. Giles ${ }^{1,2}$, I. Slutsker ${ }^{1,2}$, N. T. O’Neill ${ }^{3}$, T. F. Eck $^{2,4}$, A. Macke ${ }^{5}$, P. Croot $^{6}$, Y. Courcoux ${ }^{7}$, S. M. Sakerin ${ }^{8}$, T. J. Smyth ${ }^{9}$, T. Zielinski ${ }^{10}$, G. Zibordi ${ }^{11}$, J. I. Goes ${ }^{12}$, M. J. Harvey ${ }^{13}$, P. K. Quinn ${ }^{14}$, N. B. Nelson ${ }^{15}$, V. F. Radionov ${ }^{16}$, C. M. Duarte ${ }^{17}$, R. Losno $^{18}$, J. Sciare $^{19}$, K. J. Voss $^{20}$, S. Kinne ${ }^{21}$, N. R. Nalli ${ }^{22}$, E. Joseph ${ }^{23}$, K. Krishna Moorthy ${ }^{24}$, D. S. Covert ${ }^{25}$, S. K. Gulev ${ }^{26}$, G. Milinevsky ${ }^{27}$, P. Larouche ${ }^{28}$, S. Belanger ${ }^{29}$,

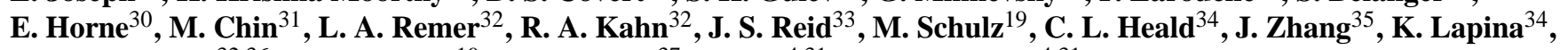
R. G. Kleidman ${ }^{32,36}$, J. Griesfeller ${ }^{19}$, B. J. Gaitley ${ }^{37}$, Q. $^{4 a n}{ }^{4,31}$, and T. L. Diehl $\mathbf{l}^{4,31}$

${ }^{1}$ Sigma Space Corporation, Lanham, Maryland, USA

${ }^{2}$ Biospheric Sciences Branch, NASA Goddard Space Flight Center, Greenbelt, Maryland, USA

${ }^{3}$ CARTEL, Université de Sherbrooke, Sherbrooke, Québec, Canada

${ }^{4}$ Goddard Earth Sciences and Technology Center, University of Maryland, Baltimore County, Baltimore, Maryland, USA

${ }^{5}$ Leibniz Institute for Tropospheric Research, Leipzig, Germany

${ }^{6}$ Leibniz Institute of Marine Sciences at the University of Kiel (IFM-GEOMAR), Kiel, Germany

${ }^{7}$ L'Observatoire de Physique de l'Atmosphère de la Réunion (OPAR), Université de la Réunion,

Saint Denis de la Réunion, France

${ }^{8}$ Institute of Atmospheric Optics, Russian Academy of Sciences, Siberian Branch, Tomsk, Russia

${ }^{9}$ Plymouth Marine Laboratory, Plymouth, UK

${ }^{10}$ Institute of Oceanology, Polish Academy of Sciences, Sopot, Poland

${ }^{11}$ Institute for Environment and Sustainability, Joint Research Centre, European Commission, Ispra, Italy

${ }^{12}$ Bigelow Laboratory for Ocean Sciences, West Boothbay Harbor, Maine, USA

${ }^{13}$ National Institute of Water and Atmospheric Research, Wellington, New Zealand

${ }^{14}$ NOAA Pacific Marine Environmental Laboratory, Seattle, Washington, USA

${ }^{15}$ Institute for Computational Earth System Science, University of California, Santa Barbara, California, USA

${ }^{16}$ Arctic and Antarctic Research Institute, Saint Petersburg, Russia

${ }^{17}$ IMEDEA (CSIC-UIB), Instituto Mediterráneo de Estudios Avanzados, Esporles (Mallorca), Spain

${ }^{18}$ Laboratoire Interuniversitaire des Systèmes Atmosphériques, Université de Paris 7 et Université de Paris 12, Creteil, France

${ }^{19}$ Laboratoire des Sciences du Climat et de l'Environnement, Gif-sur-Yvette, France

${ }^{20}$ Physics Department, University of Miami, Coral Gables, Florida, USA

${ }^{21}$ Institute for Meteorology, University of Hamburg, Hamburg, Germany

${ }^{22}$ NOAA/NESDIS Center for Satellite Applications and Research (STAR), Camp Springs, Maryland, USA

${ }^{23}$ Department of Physics and Astronomy, Howard University, Washington, DC, USA

${ }^{24}$ Space Physics Laboratory, Vikram Sarabhai Space Centre, Trivandrum, India

${ }^{25}$ Department of Atmospheric Sciences, University of Washington, Seattle, Washington, USA

${ }^{26}$ P. P. Shirshov Institute of Oceanology, Russian Academy of Sciences, Moscow, Russia

${ }^{27}$ Space Physics Laboratory, Taras Shevchenko National University of Kyiv, Kyiv, Ukraine

${ }^{28}$ Institut Maurice-Lamontagne, Mont-Joli, Québec, Canada

${ }^{29}$ Département de biologie, chimie et géographie, Université du Québec à Rimouski, Rimouski, Québec, Canada

${ }^{30}$ Bedford Institute of Oceanography, Bedford, Nova Scotia, Canada

${ }^{31}$ Atmospheric Chemistry and Dynamics Branch, NASA Goddard Space Flight Center, Greenbelt, Maryland, USA

${ }^{32}$ Climate and Radiation Branch, NASA Goddard Space Flight Center, Greenbelt, Maryland, USA

${ }^{33}$ Marine Meteorology Division, Naval Research Laboratory, Monterey, California, USA

${ }^{34}$ Department of Atmospheric Science, Colorado State University, Fort Collins, Colorado, USA

${ }^{35}$ University of North Dakota, Grand Forks, North Dakota, USA

${ }^{36}$ Science Systems and Applications, Inc., Lanham, Maryland, USA

${ }^{37}$ Jet Propulsion Laboratory, California Institute of Technology, Pasadena, California, USA

Received: 21 December 2010 - Published in Atmos. Meas. Tech. Discuss.: 8 January 2011

Revised: 11 March 2011 - Accepted: 15 March 2011 - Published: 21 March 2011

Published by Copernicus Publications on behalf of the European Geosciences Union. 
Abstract. The Maritime Aerosol Network (MAN) has been collecting data over the oceans since November 2006. Over 80 cruises were completed through early 2010 with deployments continuing. Measurement areas included various parts of the Atlantic Ocean, the Northern and Southern Pacific Ocean, the South Indian Ocean, the Southern Ocean, the Arctic Ocean and inland seas. MAN deploys Microtops handheld sunphotometers and utilizes a calibration procedure and data processing traceable to AERONET. Data collection included areas that previously had no aerosol optical depth (AOD) coverage at all, particularly vast areas of the Southern Ocean. The MAN data archive provides a valuable resource for aerosol studies in maritime environments. In the current paper we present results of AOD measurements over the oceans, and make a comparison with satellite AOD retrievals and model simulations.

\section{Introduction}

Atmospheric aerosol optical studies, involving radiative forcing analysis, aerosol-cloud interactions, remote sensing of the atmosphere, and global aerosol modeling require accurate information on aerosol optical depth (AOD). Sea salt is a major contributor to the columnar AOD over the oceans (Mahowald et al., 2006), and therefore affects the radiation budget directly (e.g. Haywood et al., 1999) and indirectly (O'Dowd et al., 1999). The complexity of aerosol production (Lewis and Schwartz, 2004) and advection from land sources warrant systematic measurements of aerosol optical parameters in maritime environments. Statistical robustness is required to better understand regional aerosol climatology and trends derived from the long-term satellite records.

Generally speaking, not all areas of the World Ocean can be studied from islands; aside from environmental satellites, ships are the only platform whereby measurements can be obtained. Ideally, a long-term comprehensive program is needed to include AOD on the list of routine meteorological and/or scientific measurements carried out onboard research vessels. Since network-grade stabilized platforms with automatic instrumentation capable of producing highly accurate AOD are not yet available, hand-held instruments continue to be the only option for shipboard AOD data collection. Therefore, the establishment of the Maritime Aerosol Network (MAN) as a component of the Aerosol Robotic Network (Smirnov et al., 2009) has been a key step towards meeting this data need. MAN exploits the existence of the advanced AERONET calibration facilities and processing schemes, and relies on many logistical and scientific developments from the AERONET Project. The MAN webbased public data archive is a part of the AERONET web

Correspondence to: A. Smirnov (alexander.smirnov-1@nasa.gov) site. MAN represents an important strategic sampling initiative and ship-borne data acquisition complements islandbased AERONET measurements.

MAN started collecting data over the oceans in November 2006 and since then has made significant progress in data collection and archival. With more than 80 cruises completed and ongoing (and many more planned), the MAN database continues to grow. MAN will enhance our knowledge of spectral AOD variation over the oceans. The ultimate objective is to advance fundamental scientific understanding of aerosol optical properties globally through highly accurate and standardized measurements.

In the current paper we present new results on aerosol optical depth measurements over the oceans and compare shipborne measurements to satellite retrievals from various sensors and to global chemical transport models.

\section{Instrumentation, measurement areas and network products}

The Maritime Aerosol Network (Smirnov et al., 2006, 2009) deploys hand held Microtops II sunphotometers and utilizes calibration and data processing procedures traceable to AERONET (Holben et al., 1998, 2001; Smirnov et al., 2004). The Microtops II Sunphotometer has five spectral channels and can accommodate several possible filter configurations within the spectral range of 340-1020 nm. Detailed descriptions of the instrument are given by Morys et al. (2001), Porter et al. (2001), and Knobelspiesse et al. (2003). The estimated uncertainty of the optical depth in each channel does not exceed \pm 0.02 (Knobelspiesse et al., 2004), primarily due to inter-calibration against AERONET reference CIMEL instruments that are accurate to $\sim 0.005$ at most wavelengths (Eck et al., 1999). Microtops II instruments have shown good calibration stability over the years. Most of the instruments were manufactured in the late 1990s and have the original filters in place. The variability in calibration coefficients within a few percent over three years relative to AERONET reference CIMELs is quite acceptable. Figure 1 shows the variability in calibration coefficients (extraterrestrial irradiance signal, $V_{0}$ ) for one particular Microtops II. Certain changes in the calibration (post-field deployment in particular) are typically associated with aerosol deposition on the optics window that occurs at sea. After window cleaning, the calibration coefficients often approximate their original (pre-deployment) values. However, for some instruments we occasionally observed filter degradation which manifests itself as a rapid change in the calibration coefficient.

The Maritime Aerosol Network measurement area has included northern and southern parts of the Atlantic Ocean; transects North-South, South-North, and East-West in the Pacific; intensive study areas in the Southern Ocean and off the coast of Antarctica including a number of circumnavigation cruises in high southern latitudes. A cruise area in 


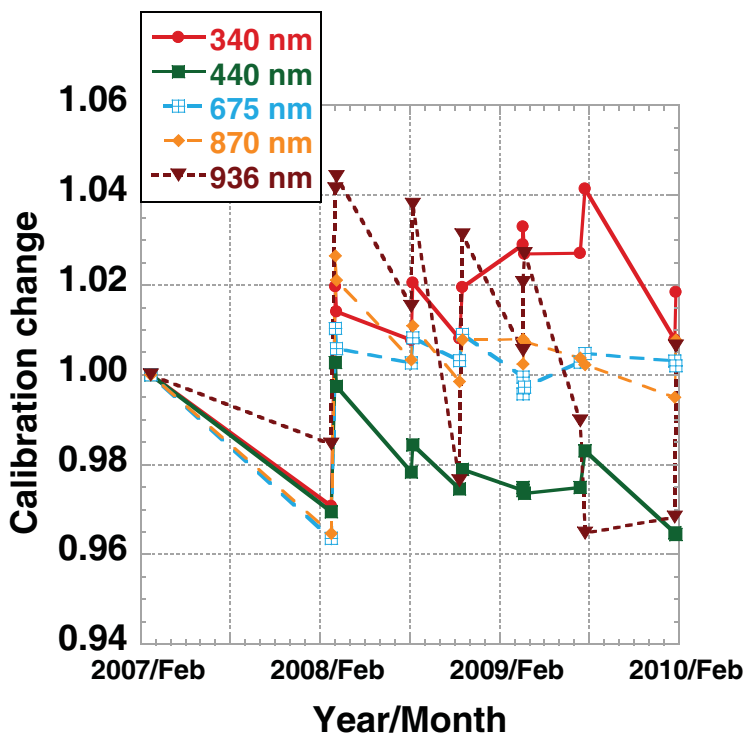

Fig. 1. Microtops (S/N 3657) calibration history.

the South Indian Ocean included the region between $\mathrm{Re}$ union, Crozet, Kerguelen and Amsterdam Islands, as well as in the Mozambique Channel. Atmospheric measurements in the Bay of Bengal, Gulf of Bothnia as well as the Arabian, Mediterranean, Black, Baltic, Norway, Bering, Beaufort Seas, represented important contributions to the database. Previously, some of those oceanic regions (e.g. the Bering Sea, the Beaufort Sea, the South Indian Ocean, coast of Antarctica) had very limited or no surface-based AOD coverage at all.

The Maritime Aerosol Network data products are:

a. Spectral AOD $\tau_{\mathrm{a}}(\lambda)$,

b. Angstrom parameter $\alpha$ (calculated using a least squares method within the $440-870 \mathrm{~nm}$ wavelength range),

c. columnar precipitable water, and

d. AOD at $500 \mathrm{~nm}$ partitioned into fine and coarse components according to the Spectral De-convolution Algorithm (SDA) by O'Neill et al. (2001, 2003).

All products have three data quality levels: Level 1.0 (unscreened), Level 1.5 (cloud-screened), and Level 2.0 (cloudscreened and quality assured). After final calibration the values of spectral AOD $\tau_{\mathrm{a}}(\lambda)$ at Level 1.5 match those at Level 2.0 except for a few possible cloud contaminated outliers that are manually removed. The SDA quality assurance criteria are more complicated in that they involve additional criteria appended onto each of the three criteria defined in the previous two sentences. We would like to point out that the SDA data-QA criteria were empirically determined and were tested on various subsets of different aerosol types. These tests were carried out for various optical conditions across the AERONET database and for the entire MAN dataset. We would like to emphasize that those criteria are in line with the AERONET SDA products; however, fine and coarse aerosol optical depth partition products for MAN have additional quality checks.

All products are available on the MAN web page, which is a part of the AERONET web site. A public domain webbased archive dedicated to the network activity can be found at: http://aeronet.gsfc.nasa.gov/new_web/maritime_aerosol_ network.html.

\section{Maritime Aerosol Network (MAN) global coverage}

MAN started regular data acquisition in November 2006 after two pilot projects were conducted (in 2004 and in the winter of 2005-2006). Since then ship cruises continued accumulating data, with over 1700 days of measurements as of March 2010. The Level 2.0 data archive is mapped in Fig. 2.

Figure 3 shows latitudinal dependence of the AOD for different oceans and seas. The oceanic data have been divided roughly by longitude among three oceans: Atlantic $\left(20^{\circ} \mathrm{E}-\right.$ $\left.70^{\circ} \mathrm{W}\right)$, Pacific $\left(70^{\circ} \mathrm{W}-150^{\circ} \mathrm{E}\right)$, and Indian $\left(20^{\circ} \mathrm{E}-150^{\circ} \mathrm{E}\right)$. We consider measurements made south of $60^{\circ} \mathrm{S}$ as belonging to the Southern Ocean. Data collection in the Arctic Ocean was limited to the Beaufort Sea area. Measurements taken over Baltic, Black and Mediterranean Seas were grouped together. The measured aerosol properties (AOD, Angstrom parameter, and coarse mode fraction of AOD) for each area are shown in Figs. 3-6.

Figure 3a shows the latitudinal dependence of AOD daily averages at a wavelength $500 \mathrm{~nm}$ over the Atlantic Ocean. One can observe a pronounced peak in the distribution within the latitudinal belt $5^{\circ}-20^{\circ} \mathrm{N}$ influenced by the dust and biomass burning aerosol transport from northern Africa. Optical depth variability is rather high ranging from typical values for the remote regions $(\sim 0.07$ at $500 \mathrm{~nm})$ to high aerosol loading close to 1.0. In the Southern Hemisphere $\tau_{\mathrm{a}}(500)$ is typically less than 0.10 ; in some cases being as low as 0.04. Aerosol optical properties in the area north of $30^{\circ} \mathrm{N}$ are highly variable probably due to the various pollution aerosol sources in Europe and episodic dust transport from Africa. A few measurements in the northern areas near Greenland and Spitsbergen in the summer months yielded $\tau_{\mathrm{a}}(500)$ values $\sim 0.07$ (typical of background conditions over the oceans). The $\tau_{\mathrm{a}}(500)$ frequency histogram (bin size $\left.\delta \tau_{\mathrm{a}}=0.05\right)$ in Fig. 4a shows a peak at $\tau_{\mathrm{a}}(500) \sim 0.075$ and indicates that $75 \%$ of the data has $\tau_{\mathrm{a}}(500)<0.20$. However the distribution has a "tail" that contains $25 \%$ of the daily averages. Marine and dust aerosol were clearly influential in producing the small value of the Angstrom parameter $(\sim 0.3)$ seen at the peak of the frequency distribution (bin size $\delta \alpha=0.20)$ of Fig. 5a. The spectral de-convolution algorithm allows the partition of aerosol optical depth into fine and coarse parts. The SDA-estimated coarse mode fraction 


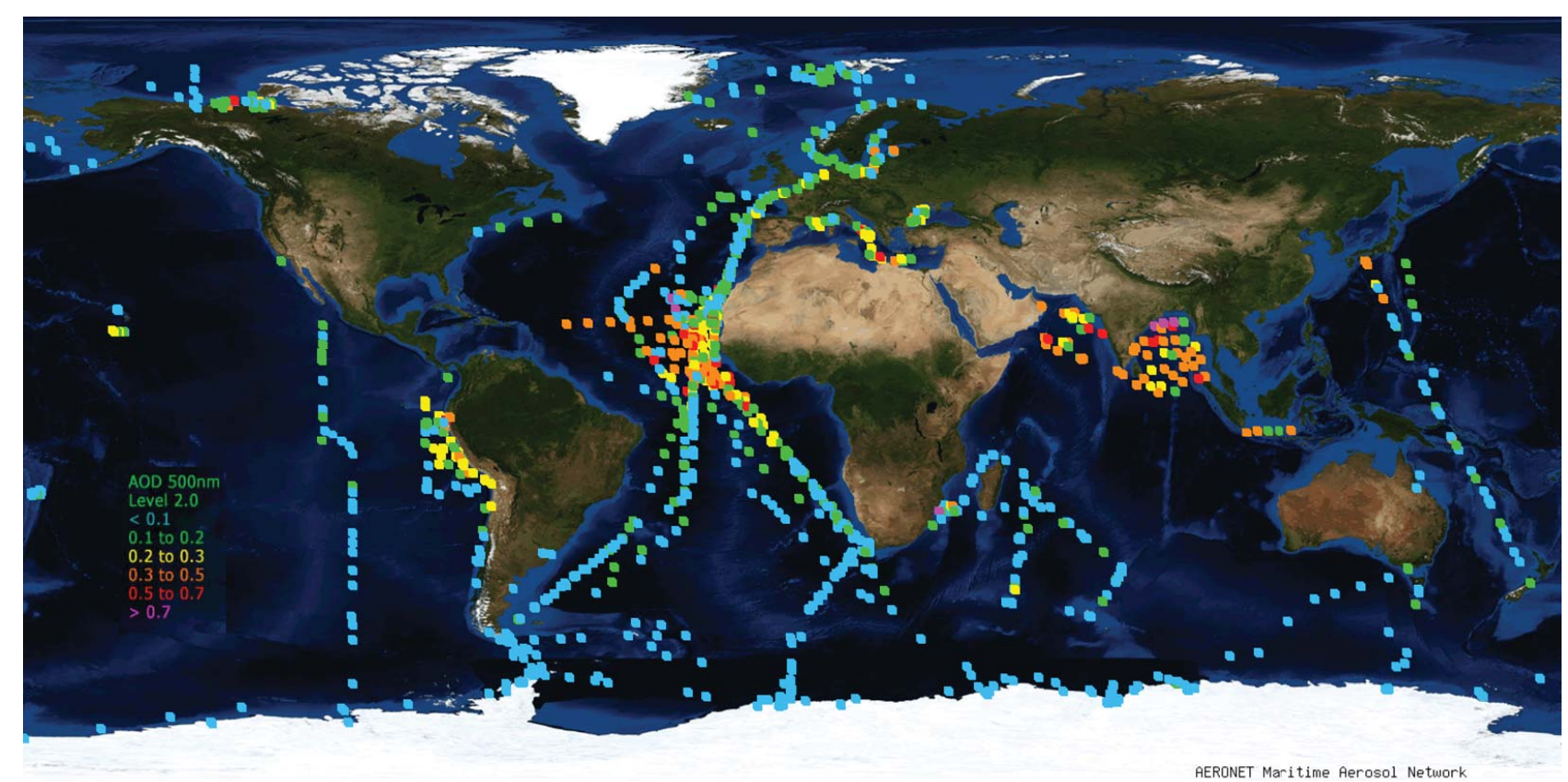

Fig. 2. Maritime Aerosol Network global coverage - cruise tracks and daily averages of aerosol optical depth at $500 \mathrm{~nm}$ (squares are colored with respect to $\mathrm{AOD}$ values, i.e. blue $-\mathrm{AOD}<0.10$, green $-0.1 \leq \mathrm{AOD}<0.2$, yellow $-0.2 \leq \mathrm{AOD}<0.3$, orange $-0.3 \leq \mathrm{AOD}<0.5$, red $0.5 \leq \mathrm{AOD}<0.7$, purple $-\mathrm{AOD} \geq 0.7$ ).

(ratio of coarse mode AOD to total AOD at a wavelength of $500 \mathrm{~nm}$ ) varies mainly within the $0.6-0.8$ range in regions where marine and dust aerosols are dominant while being significantly different for the regions where pollution and biomass burning aerosols to be more predominant (0.2-0.4). Frequency distribution of the coarse mode fraction (Fig. 6a) (bin size $=0.1$ ) peaks at 0.75 with over $60 \%$ of occurrences within the $0.5-0.8$ range.

According to the AERONET island stations in the Pacific and available publications summarized by Smirnov et al. (2002), the remote areas are typically characterized by $\tau_{\mathrm{a}}(500)$ values $\sim 0.07$. Overall this observation was confirmed by MAN ship-based measurements (Fig. 3b). However, aerosol optical properties were highly variable (AODs ranged from 0.10 to 0.45 ) near Japan (heavily influenced by pollution aerosol and dust from Asia), and were occasionally elevated (a few days with AODs $\sim 0.20$ and higher were recorded) near the island of Hawaii, and the average AOD was $\sim 0.20$ near the West coast of South America at tropical latitudes. In the Pacific the bi-modal frequency distributions of $\tau_{\mathrm{a}}(500)$ and the Angstrom parameter (Figs. $4 \mathrm{~b}$ and $5 \mathrm{~b}$ ) are indicative of two optical conditions. The first is associated with the remote ocean with peak values near $\tau_{\mathrm{a}}(500) \sim 0.07$ and $\alpha \sim 0.5$. The second modal feature has a most probable optical depth of $\sim 0.23$ and $\alpha \sim 1.0$. Therefore, in this latter case the fine mode aerosol fraction contributes more than $50 \%$ to the total AOD. The coarse mode fraction frequency distribution (Fig. 6b) peaks at 0.65 ; however, it is wider than in the Atlantic (Fig. 6a) with almost equal frequencies within the range of $0.2-0.6$.
Significant progress has been made in data collection over the Indian Ocean (Fig. 3c). Measurements over the Arabian Sea and the Bay of Bengal demonstrated a variety of optical conditions. AOD values were quite high with daily averages largely over 0.20 . Overall, the AOD over the Bay of Bengal was higher and also produced greater spectral dependence (high Angstrom parameter indicative of a dominant fine mode particle contribution) (see also Moorthy et al. 2010). Optical properties in the region between Reunion and Tromelin islands and in the Mozambique Channel were highly variable. Continental aerosol plumes frequently appear in the area with at least one possible case of biomass burning aerosol from Africa (12 November 2009) with $\tau_{\mathrm{a}}(500) \sim 0.60$ and $\alpha \sim 1.4$. Measurements in the South Indian Ocean in the area between Reunion, Amsterdam, Crozet and Kerguelen Islands yielded optical depths ranging between 0.02-0.10. This low optical depth phenomenon is quite repeatable and was reported elsewhere (Barteneva et al., 1991) based on the results of a number of cruises conducted in the beginning of the 80s (see also summary in Smirnov et al., 2002). According to Barteneva et al. (1991) at $500 \mathrm{~nm}$ AODs ranged within $0.05-0.11$ to the north of the Antarctic Convergence zone (up to $40^{\circ} \mathrm{S}$ ) and $0.03-0.04$ to the south of it. Recently Vinoj et al. (2007) reported AODs less than 0.10 at $500 \mathrm{~nm}$ in the Indian Ocean south of $40^{\circ} \mathrm{S}$.

The frequency of occurrences (Fig. 4c) shows that on 55\% of all days $\tau_{\mathrm{a}}(500)$ was below 0.10 , whereas for $20 \%$ of cases it was over 0.30 . The histogram presents evidence of a narrow peak and a wide second peak. The latter peak is attributed to the variety of optical conditions over the Arabian 

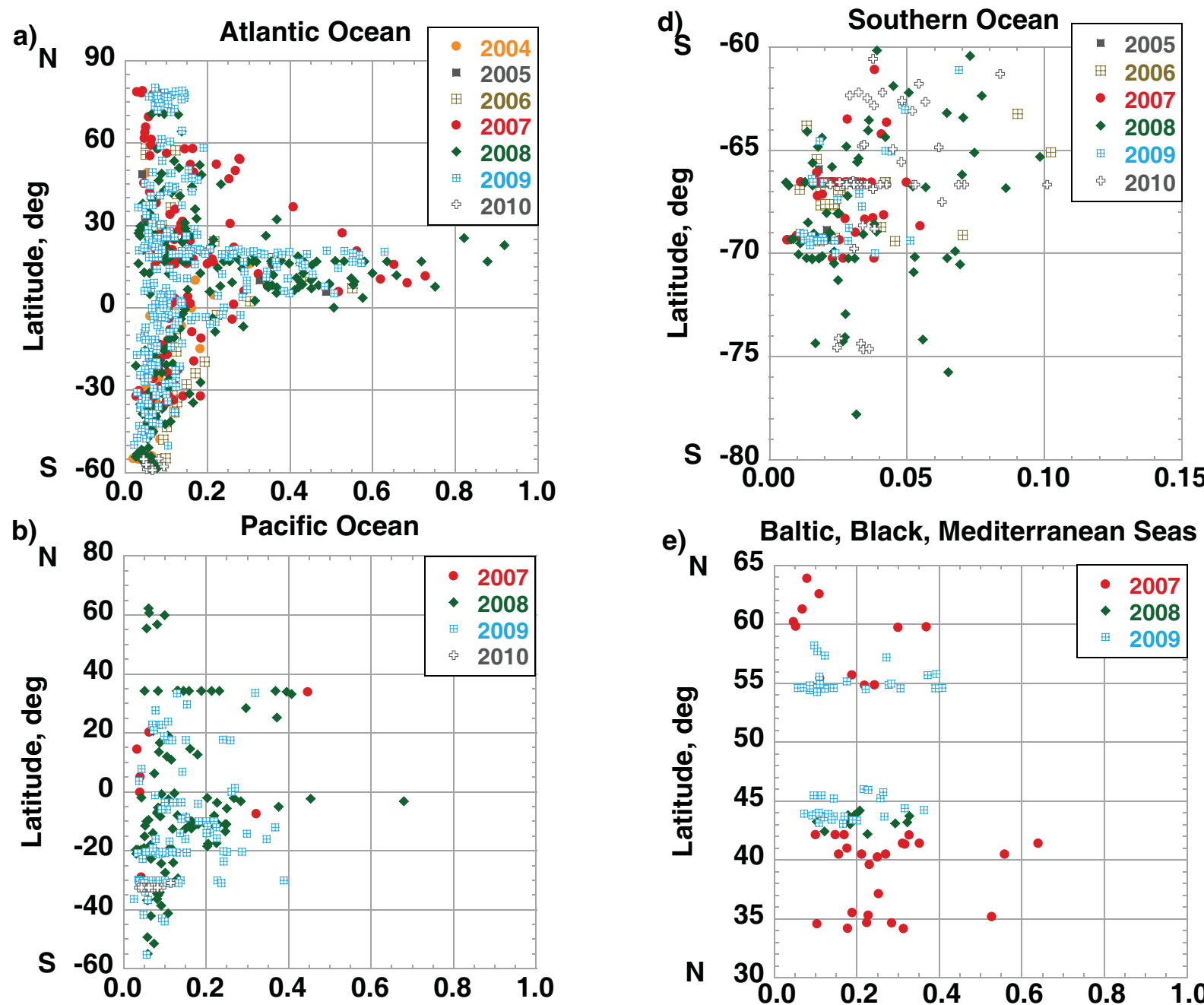

e) Baltic, Black, Mediterranean Seas
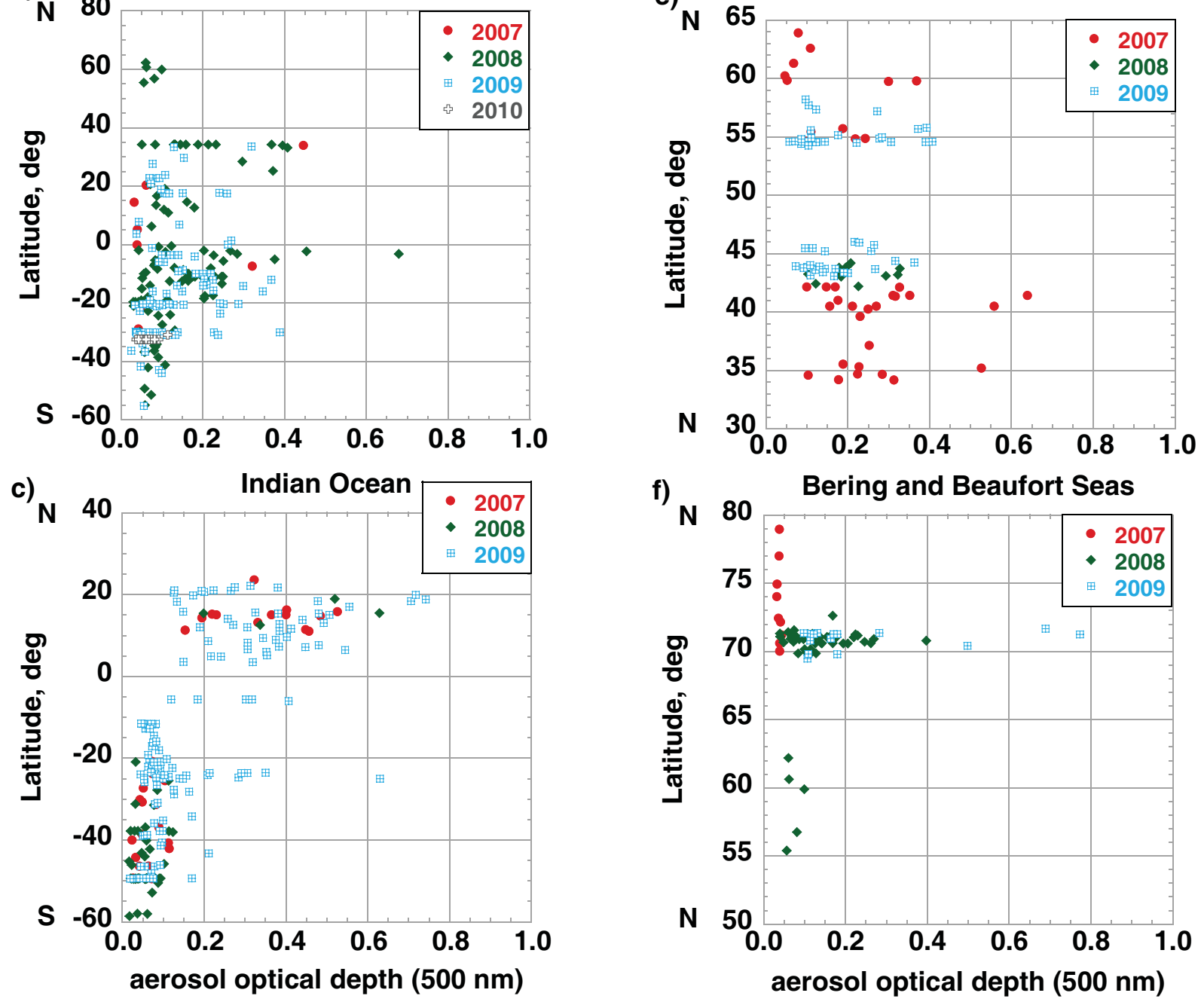

Fig. 3. Latitudinal dependence of daily averaged aerosol optical depth in the Atlantic Ocean (a), Pacific Ocean (b), Indian Ocean (c), Southern Ocean (d), Baltic, Black, and Mediterranean Seas (e), Bering and Beaufort Seas (f). 


$$
\text { a) }
$$
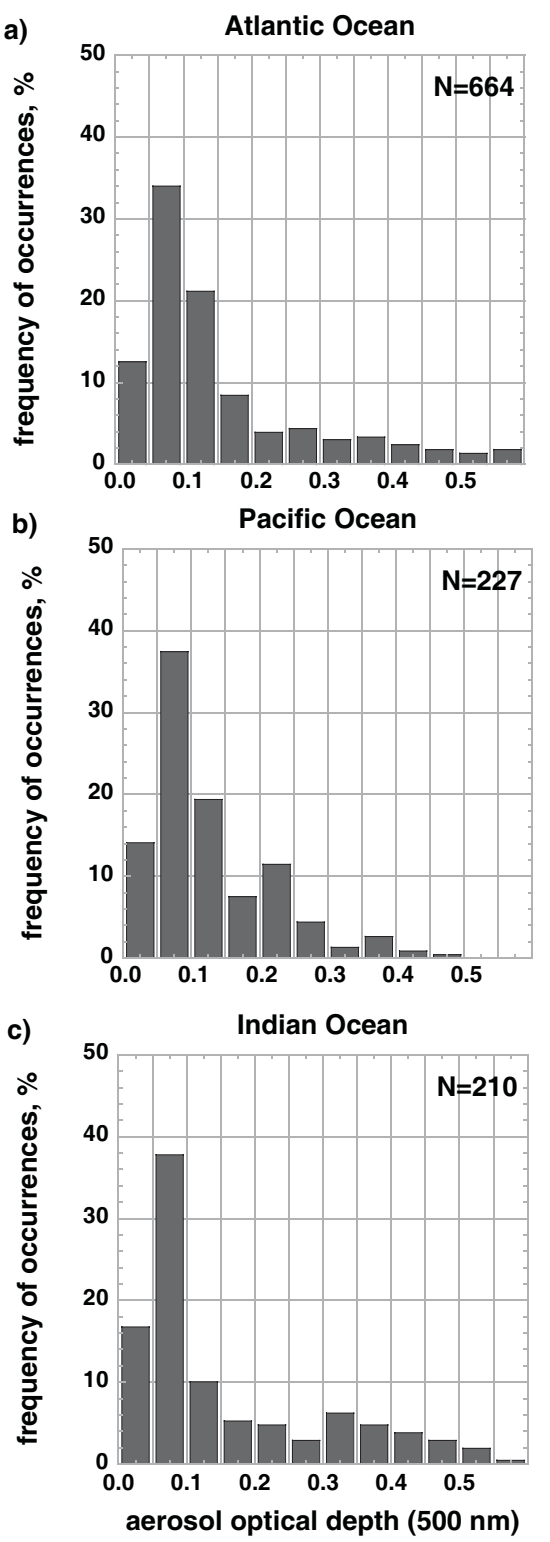

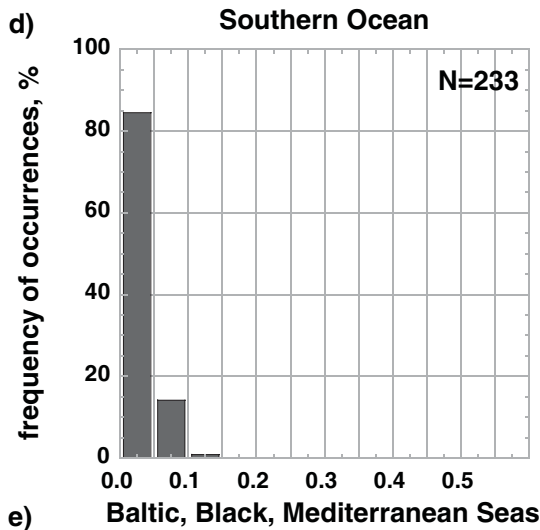

e)
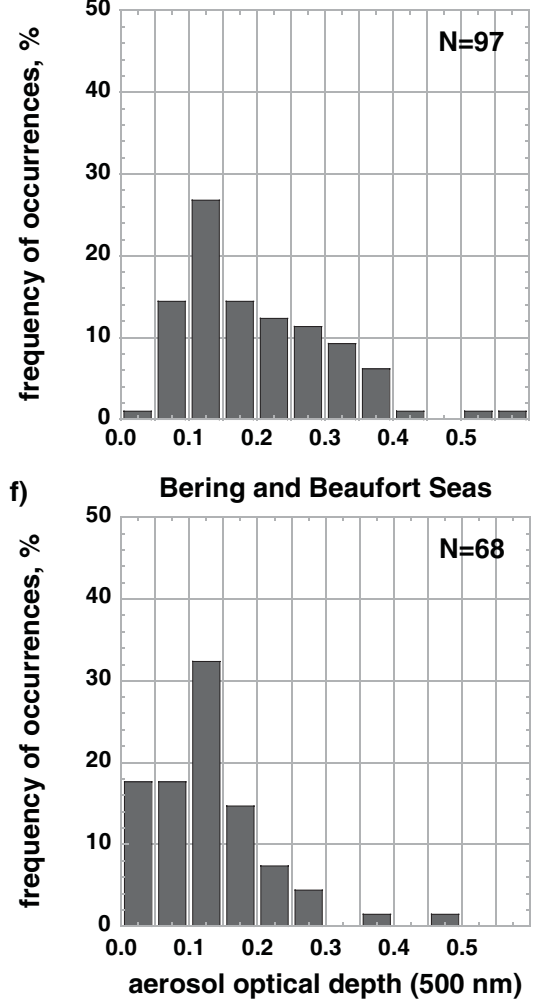

Fig. 4. Frequency of occurrences of daily averaged aerosol optical depth at $500 \mathrm{~nm}$ for (a) Atlantic Ocean, (b) Pacific Ocean, (c) Indian Ocean, (d) Southern Ocean, (e) Baltic, Black, and Mediterranean Seas, (f) Bering and Beaufort Seas.

Sea and the Bay of Bengal, related to dust and pollution emission from adjacent continental regions. The Angstrom parameter frequency distribution (Fig. 5c) shows a relatively neutral spectral dependence (typical for clean remote ocean areas and turbid dusty conditions) and a secondary peak around 1.3 which can be attributed mainly to the polluted air in the Bay of Bengal and near coast of Africa (high AOD cases). This secondary peak was not linked in any simple fashion to the secondary peak of the AOD histogram. Similar bimodal structure is evident for the coarse mode fraction of AOD (Fig. 6c). In this case we can identify the first peak at 0.15 as associated with the pollution in the Bay of Bengal whereas the second broad peak $(\sim 0.65)$ is associated with dust over Arabian Sea and clean maritime conditions over other measurement areas.

Measurements in the Southern Ocean yielded the results shown in Fig. 3d. AOD at $500 \mathrm{~nm}$ was quite low; over $80 \%$ of the data points were less than 0.05 in the frequency histogram (Fig. 4d). Day to day variation was minimal. The broad maximum in the Angstrom parameter frequency distribution is likely due to the higher uncertainty in $\alpha$ computations when $\tau_{\mathrm{a}}$ is low. We would like to point out that this area of the Southern Ocean previously had almost no AOD measurement coverage at all; this is another example of how the MAN approach yields geo-statistical benefits which are difficult if not impossible to reproduce using other 
a)

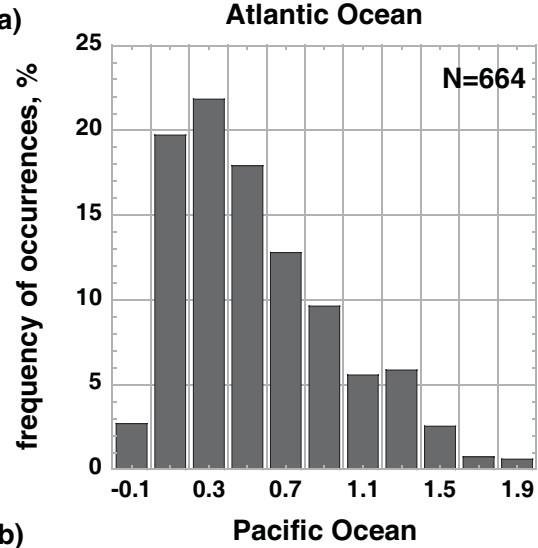

b)

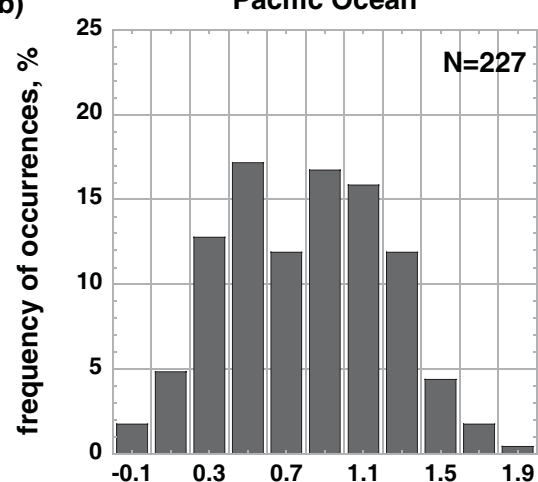

c)

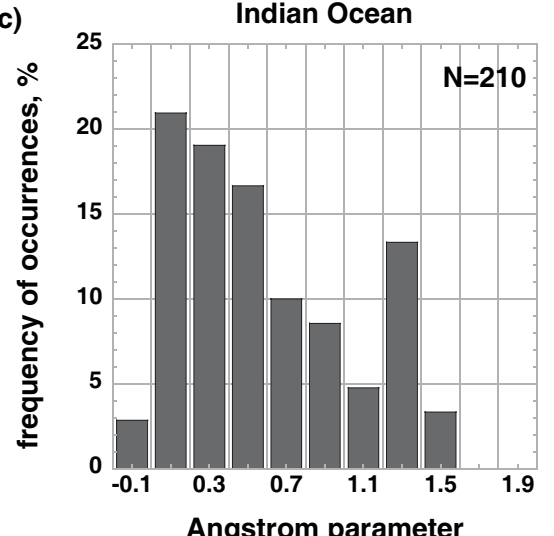

d)

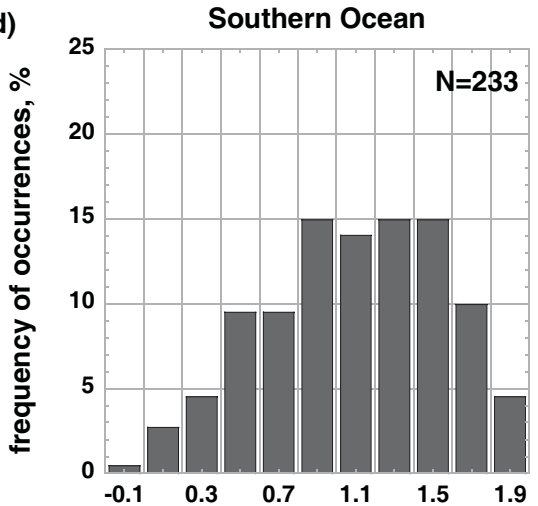

e)

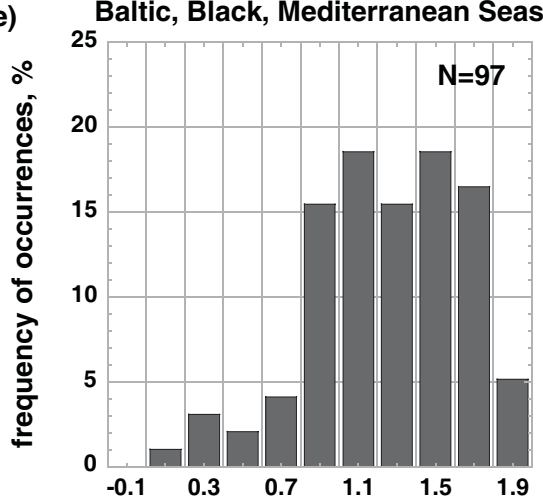

f)

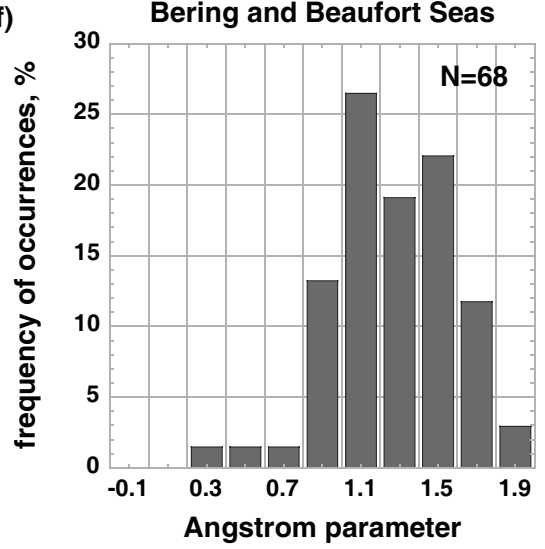

Fig. 5. Frequency of occurrences of daily averaged Angstrom parameter for (a) Atlantic Ocean, (b) Pacific Ocean, (c) Indian Ocean, (d) Southern Ocean, (e) Baltic, Black, and Mediterranean Seas, (f) Bering and Beaufort Seas.

remote sensing techniques. Measurements in the Southern Ocean are comparable to the AERONET-based and other (see Tomasi et al., 2007) coastal measurements in Antarctica $\left[\tau_{\mathrm{a}}(500) \sim 0.02-0.03\right]$.

Several cruises conducted in the Mediterranean, Black, Baltic Seas including the Gulf of Bothnia provided a useful but relatively small dataset. Aerosol optical depth was highly variable (Fig. 3e) changing mainly within $0.10-0.40$ range, except for the Gulf of Bothnia where $\tau_{\mathrm{a}}(500)$ was less than 0.10. Data collection in the Beaufort Sea area (Fig. 3f, north of $65^{\circ} \mathrm{N}$ ) enabled the characterization of background conditions during the summer of $2007\left(\tau_{\mathrm{a}}(500) \sim 0.04\right)$ as well as capturing Arctic haze events in the spring of 2008. A variety of optical conditions, such as biomass burning aerosol transported from Alaska were found during the summer of 2009. Data acquired in the Bering Sea are included in Fig. $3 \mathrm{f}$ in order to provide a basis for comparison with other MAN data. While limited to only five days of measurements, it shows $\tau_{\mathrm{a}}(500)$ to be $\sim 0.06-0.08$, which is comparable to the remote Pacific Ocean data but higher than Beaufort Sea background results by a factor of $\sim 1.5$ to 2 . Figures $4 \mathrm{f}$ and $5 \mathrm{f}$ permit a direct comparison of the AOD and Angstrom 

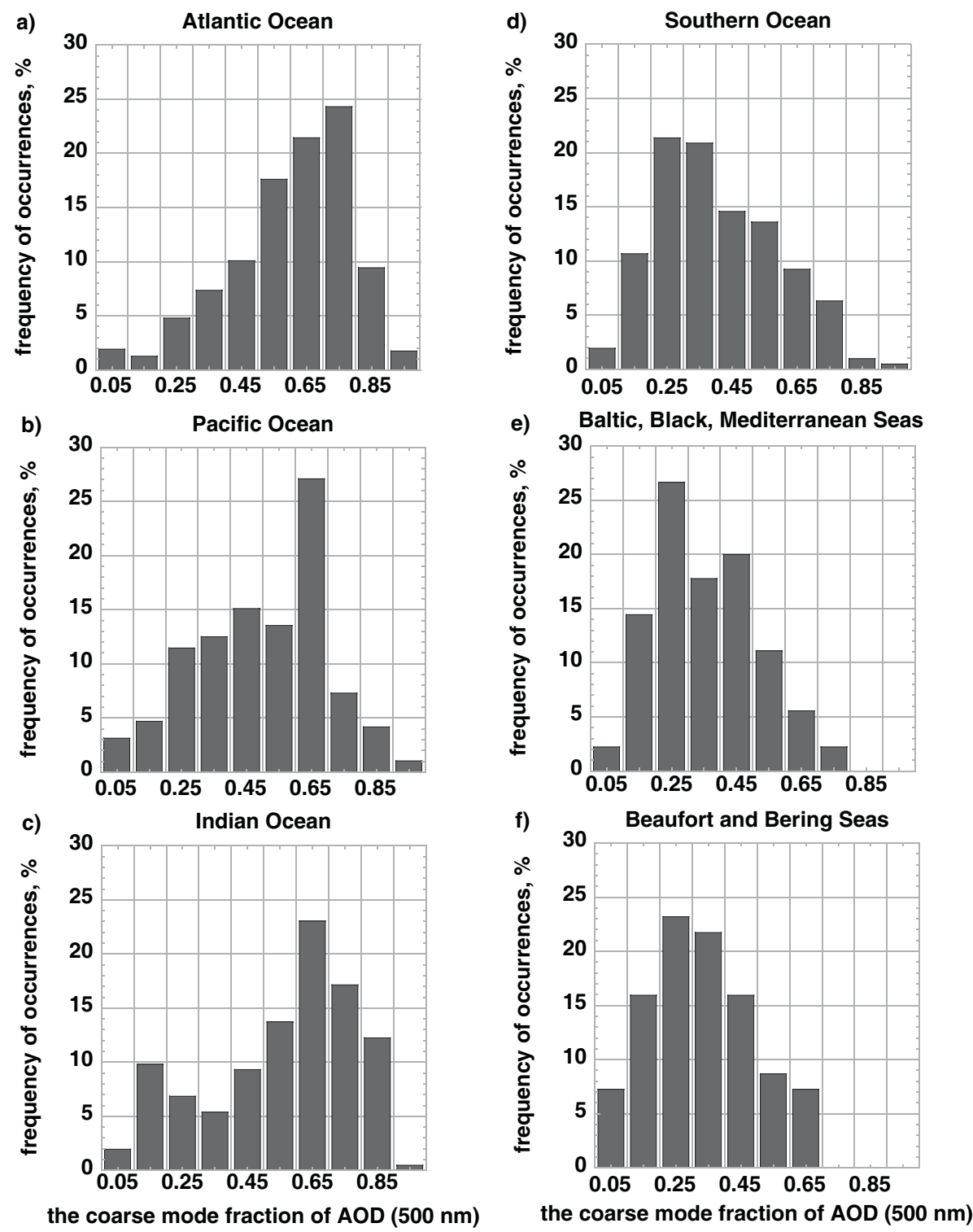

Fig. 6. Frequency of occurrences of the daily averaged coarse mode fraction for (a) Atlantic Ocean, (b) Pacific Ocean, (c) Indian Ocean, (d) Southern Ocean, (e) Baltic, Black, and Mediterranean Seas, (f) Bering and Beaufort Seas.

parameters with other regions. Measurements presented in Figs. 3-6 (e,f) were carried out in different regions and in various seasons when optical conditions were determined by a mixture of maritime and continental aerosols. The scatter of the aerosol optical parameters is evident but $\alpha$, in the majority of cases is higher than 1.0, which is an indication of the significant contribution of fine particles to the attenuation in the atmospheric column (the coarse mode fraction of AOD varies mainly within $0.1-0.5$ range). The most frequent AOD is $\sim 0.12$ for both subsets (Fig. $4 \mathrm{e}-\mathrm{f}$ ); however, AOD frequencies are skewed towards higher AODs in the Baltic, Black, and Mediterranean Seas (Fig. 4e) and towards smaller AODs in the Bering and Beaufort Seas (Fig. 4f).
Overall statistics for oceanic areas (we did not include inland seas - Baltic, Black, and Mediterranean) are presented in Fig. 7. Despite the fact that vast areas still have limited or no coverage we can delineate some general characteristic features of aerosol optical properties over the oceans:

- AOD at a wavelength $500 \mathrm{~nm}$ is less than 0.10 over oceanic areas not influenced by continental pollution, smoke or dust outflows - Fig. 7a.

- The Angstrom parameter (a general indicator of aerosol particle size) is generally smaller $(<0.50)$ than values reported over continents (Holben et al., 2001) and in many instances less than values reported over island sites (Smirnov et al., 2002, 2009) - Fig. 7b. Desert dust 

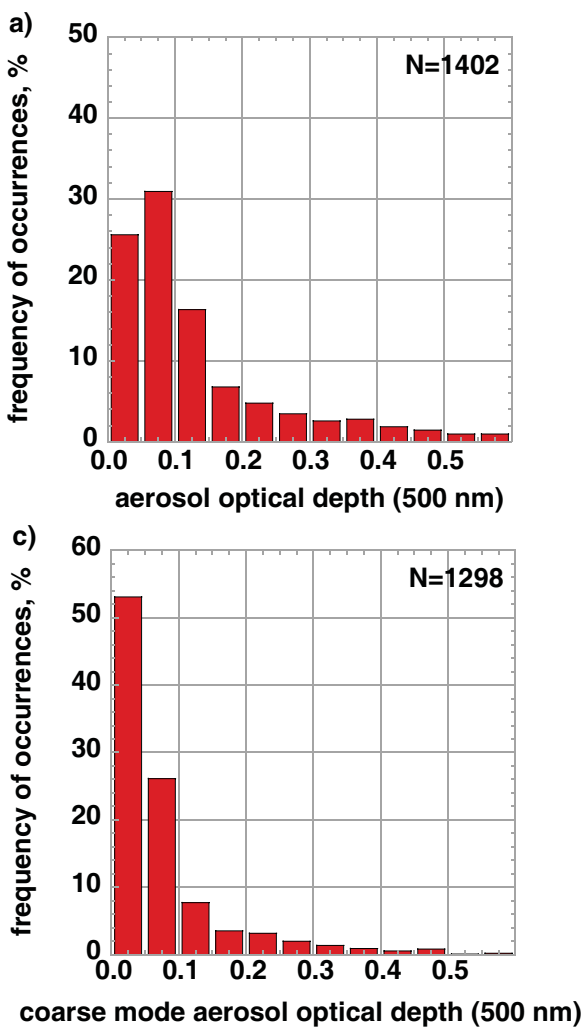
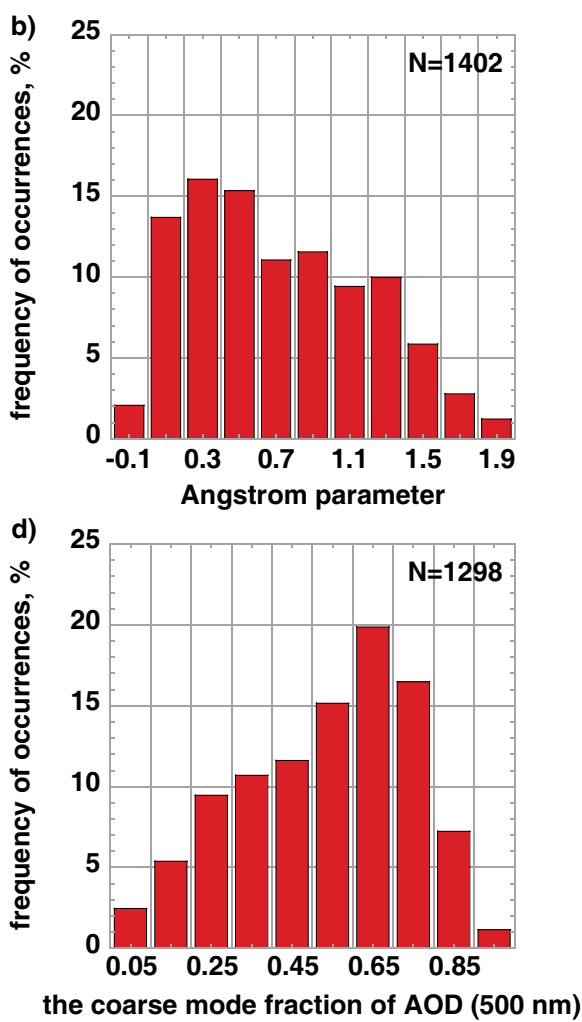

Fig. 7. Frequency of occurrences of daily averaged AOD (a), Angstrom parameter (b), coarse mode AOD (c), coarse mode fraction of AOD (d) for oceanic areas excluding the inland seas.

contributed about $10 \%$ to the overall daily statistics if we consider $\mathrm{AOD}>0.2$ and $\alpha<0.6$ as thresholds for a dust subset.

- The coarse mode AOD at $500 \mathrm{~nm}$ is less than 0.10 for the vast majority of occurrences - Fig. $7 \mathrm{c}$.

- Over $50 \%$ of the coarse mode fraction is within the range $0.50-0.80$, denoting dominance of coarse aerosol in the total aerosol optical depth - Fig. 7 d.

\section{Comparison with satellite retrievals and global transport models}

The ship-borne measurements provide an excellent opportunity for comparison with global aerosol transport models and satellite retrievals. AOD differences between satellite retrievals or model simulations and ship-borne AODs are presented in this section. In order to better visualize comparisons we present AOD differences as a function of latitude against MAN ground-truth for each sensor or model. Sunphotometer measurement series (Level 2.0) were spectrally adjusted using log-log interpolation to the "validation" wavelength of $550 \mathrm{~nm}$.
The global model GOCART is driven by the assimilated meteorological fields from the Goddard Earth Observing System Data Assimilation System (GEOS4-DAS) and simulates major aerosol types of dust, sulfate, black carbon, organic matter, and sea salt (details described in Chin et al., 2002, 2009, and references therein). GOCART simulated aerosol optical depth used in this study is archived at $1^{\circ}$ latitude by $1.25^{\circ}$ longitude spatial resolution every three hours. For comparisons in this study, the GOCART output was extracted to match the MAN observations at the closest location and time.

GEOS-Chem (www.geos-chem.org) is a global chemical transport model driven by assimilated meteorology from the NASA Global Modeling and Assimilation Office (GMAO). Simulations shown here were performed with v8-03-01 of the model with GEOS-5 meteorology at $2^{\circ} \times 2.5^{\circ}$ horizontal resolution (degraded from $0.5^{\circ} \times 0.67^{\circ}$ ) and 47 vertical levels. The total AOD shown here includes contributions from sulfate, nitrate, ammonium, black carbon, organic carbon, sea salt and dust. Aerosol optical properties are based on the Global Aerosol Data Set (GADS) (Kopke et al., 1997) with modifications from Drury et al. (2010) and Jaegle et al. (2010). Model output is sampled along the MAN ship tracks and matched temporally within $30 \mathrm{~min}$ (the chemistry time step of the model). 
The comparison with the median AeroCom model (Schulz et al., 2006) constructed from the output representing year 2000 simulations by twelve models (GISS, GOCART, KYU, LOA, LSCE, MATCH, MOZGN, MPI_HAM, PNNL, TM5_B, UIO_CTM, UMI; see details in Textor et al., 2006, and Kinne et al., 2006) was made in the following way. MAN data from a given day were averaged per day and the mean latitude/longitude position was calculated. AeroCom median model data were extracted for a corresponding month when ship-based observations were made and at the mean MAN location for any given day with observations available. Each day with a MAN observation thus has one corresponding model value in a $1^{\circ} \times 1^{\circ}$ grid. This "matching" was thus done differently from other models and satellite sensors but respects seasonal variability.

The number of morning (Terra) and afternoon (Aqua) MODIS retrievals matching ship-based $\tau_{\mathrm{a}}$ was quite high. The matchup criteria were a modification of Ichoku et al. (2004). We looked for any series of MAN measurements within \pm 30 min of the MODIS overpass time. MODIS was required to retrieve at least 5 out of 25 pixels in the $50 \mathrm{~km}$ box around the ship location (details are presented by Kleidman et al., 2010). In the case of multiple matching sunphotometer measurement series we took the one closest in time to the overpass if the AOD variability was small and averaged MAN series measurements if variability was large after eliminating outliers. In over $90 \%$ of the cases we selected the closest series.

The matchup criteria for the MISR (algorithm version 22) product included successful retrievals either in the $17.6 \mathrm{~km}$ MISR retrieval region containing selected ship-based measurement (the "central" region), or in one or more of the eight retrieval regions surrounding the central one. The MAN time series for each coincidence include at least one AOD measurement during the hour before the MISR overpass, and at least one during the hour after the overpass (Kahn et al., 2005, 2010). The number of matching cases for MISR is limited (only 61 match-ups) with several outliers. Five out of seven outliers were identified as being cloud contaminated (Kahn et al., 2010). The proximity of a coastline in one case and an ice surface in the other case complicated the retrieval process for the other two outliers.

Zhang and Reid (2006) developed a methodology to minimize cloud contamination and other biases in MODIS aerosol product for implementation in operational aerosol data assimilation (DA). This DA quality level-3 Terra MODIS and Aqua MODIS AODs (Zhang and Reid, 2006; Shi et al., 2010) will be used in this study (marked as DA data assimilation quality assured). The over ocean collection 5 MODIS level-2 AODs (marked as Standard) are included for comparison. We consider any pairs of MODIS and MAN series data within $\pm 30 \mathrm{~min}$ of the overpass time and spatially within $30 \mathrm{~km}$. If more than one MAN series data point is available then we pick the closest in time.
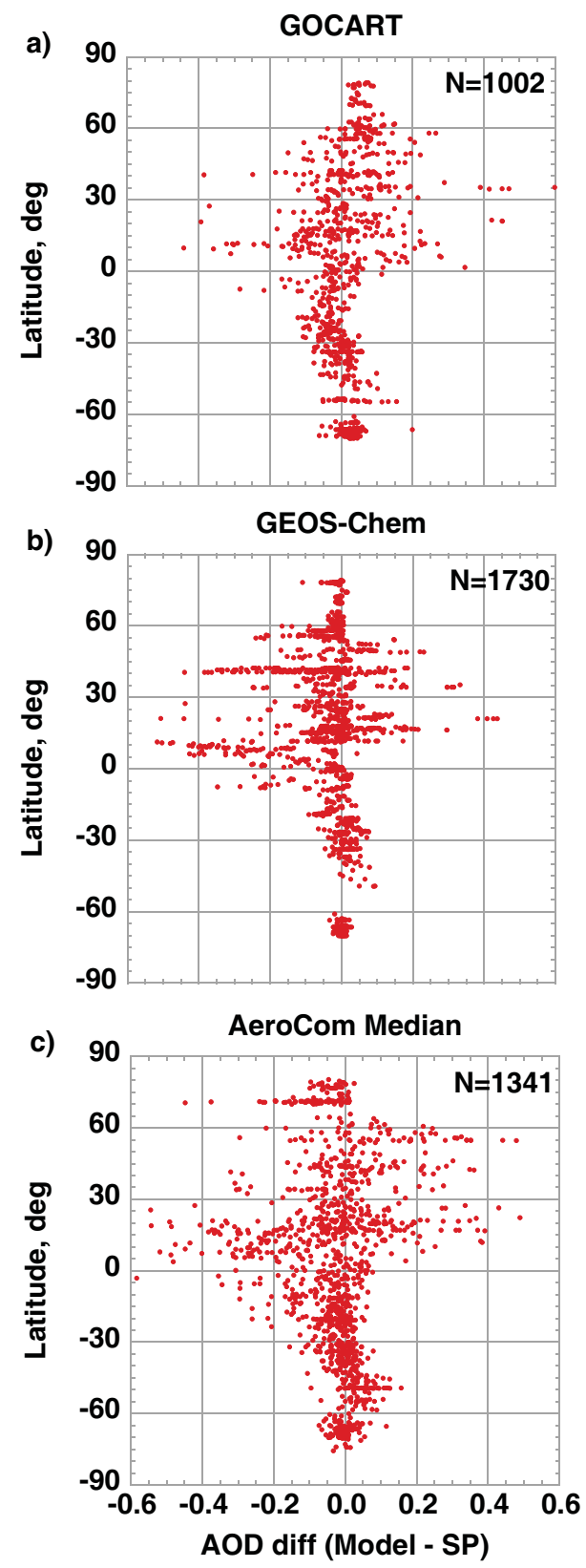

Fig. 8. Latitudinal dependence of aerosol optical depth differences between various global aerosol transport models and sunphotometer.

The temporal and spatial scale differences between point measurements from MAN and area-grids from satellite retrievals and model simulations may lead to some differences. The temporal difference is addressed by utilizing the MAN series data within a set period from the satellite or model reporting time. However, the spatial difference can only be addressed with several widely distributed measurements within the domain. As a result, some of the measurements from MAN may capture episodic aerosol plumes, which may not be detected by larger grid scale products that average over a 

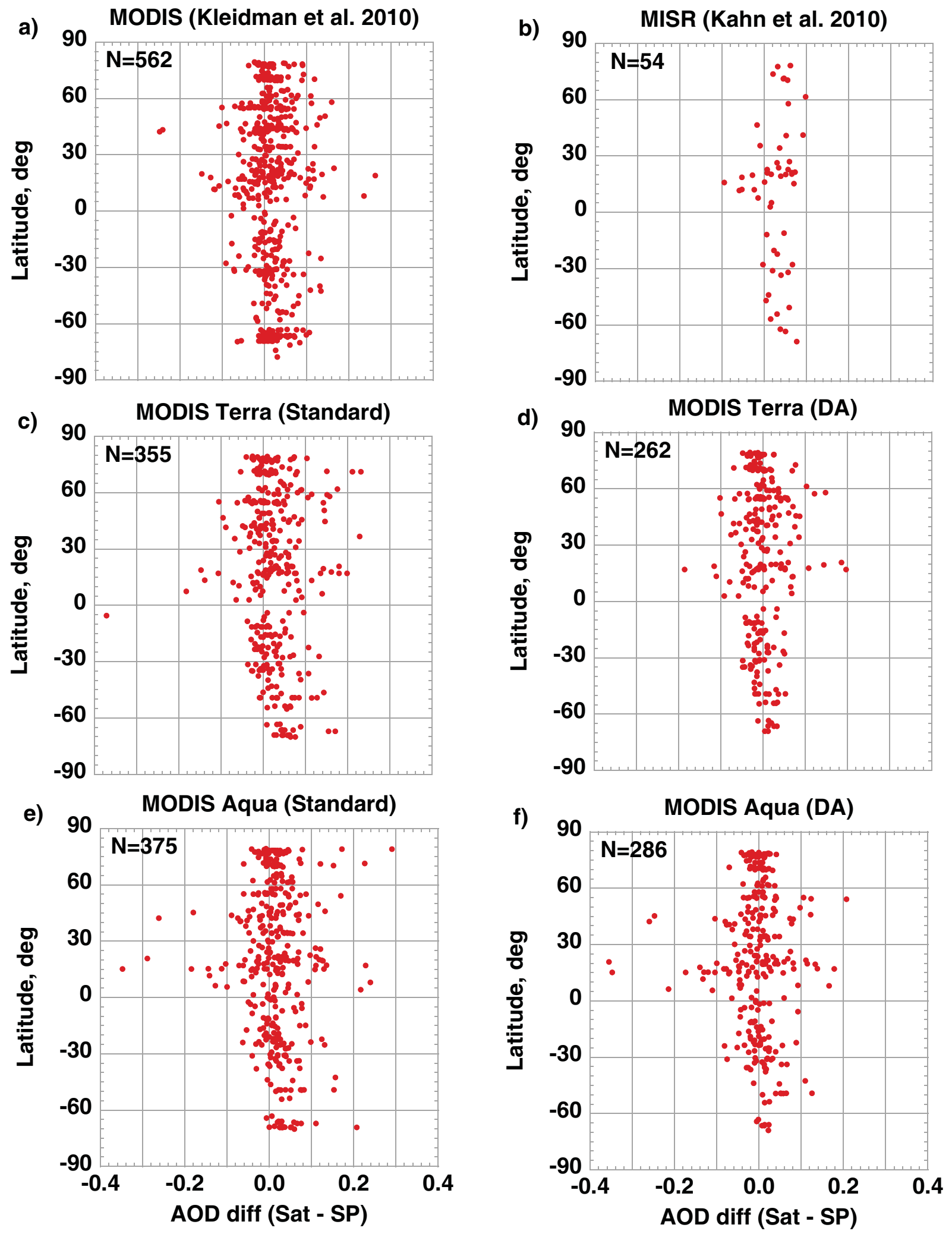

Fig. 9. Latitudinal dependence of aerosol optical depth differences between various satellite sensors and sunphotometer. 


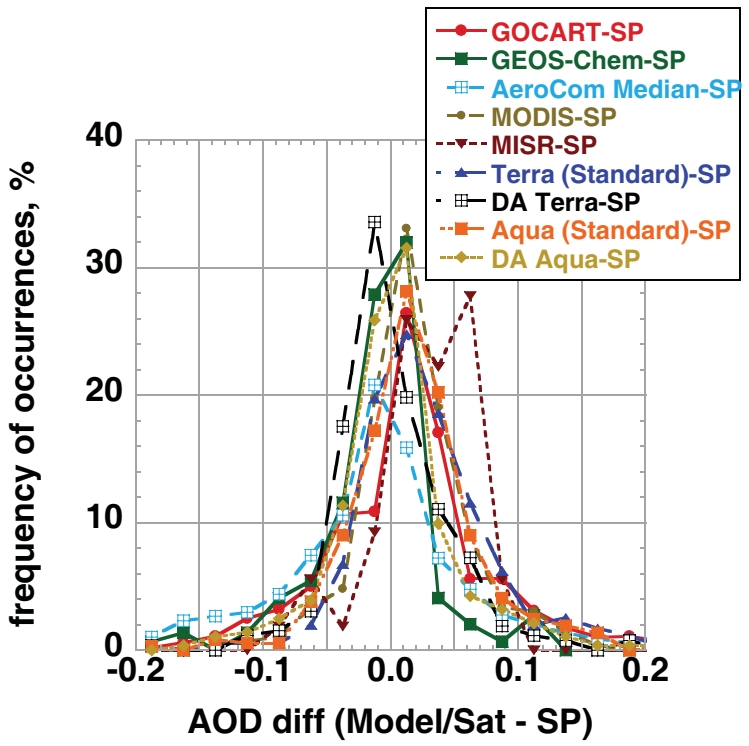

Fig. 10. Frequency of occurrences of aerosol optical depth differences between various models/sensors and sunphotometer.

large region. The spatial difference would tend to affect periods when MAN reported higher AOD and this difference would be greater for the largest area-grids.

Figure 8 presents AOD differences between global model simulations and ship-borne AODs as a function of latitude. GOCART and GEOS-Chem simulations were available only for the year 2007. From Fig. 8a one can observe that GOCART overestimates AOD more often. Positive bias is evident south of $45^{\circ} \mathrm{S}$ and north of $30^{\circ} \mathrm{N}$. A significant temporal variability in areas of the Atlantic influenced by dust and biomass burning sources produced almost symmetrical AOD differences within the belt $0^{\circ}-30^{\circ} \mathrm{N}$. While the GEOSChem model (Fig. 8b) reproduces many of the NH observations (clustering around zero bias), large negative excursions are also evident in plumes measured in 2007. The complexity of various continental sources, as well as the coarser horizontal resolution of the model simulation might explain the disparity. Unlike GOCART the GEOS-Chem and sunphotometer AOD differences are approximately equally distributed around zero south of $60^{\circ} \mathrm{S}$. The median AEROCOM model shows more scatter mainly in the Southern Hemisphere (Fig. 8c). AOD differences are mostly negative, however, distributed almost equally in the areas north of the equator to $30^{\circ} \mathrm{N}$.

Satellite retrievals from MODIS and MISR (Fig. 9a-b) indicate a positive bias, very similar to each other, although the MODIS differences are smaller. Separating Terra and Aqua retrievals would show that Terra is more severely biased high than Aqua (Remer et al., 2008). MISR and MODIS retrievals are more likely to be biased high than low over ocean, as the algorithms assume cloud-free scene and dark surfaces, whereas unscreened cloud or whitecaps, and non-zero surface reflectivity due to runoff, pollution, or biological activity, would all increase scene reflectance (Kahn et al., 2007).

The standard and data assimilation quality products for Terra MODIS comparison (Fig. 9c-d) show significant improvement in the latitudinal dependence of AOD differences. The noticeable positive bias in the Standard AOD (Fig. 9c) disappeared in the DA product (Fig. 9d). In the Northern Hemisphere differences are almost evenly distributed around zero with the $0-60^{\circ}$ degrees belt, while changing the sign of the AOD differences further north of $60^{\circ} \mathrm{N}$. The strong positive bias in the Southern Ocean for the Standard AOD became much smaller for the DA product. Comparison made for the Aqua MODIS (Fig. 9e-f) does show some improvements but no drastic changes. A number of outliers on the negative side might be associated with the unnoticed cloud contamination of the sunphotometer data.

We would like to emphasize that our analysis is not intended to determine how many retrievals are within the claimed uncertainty boundaries or beyond. Rather, we wanted to show where satellite retrieval biases exist and in what latitudinal belts corrections are needed. For example, in the southern latitudes (south of $40^{\circ}$ ) the sunphotometer AODs are low compared with satellite retrievals and modeling results. This discrepancy can be explained, at least partly, by uncertainties in aerosol production rates (Lewis and Schwartz, 2004), foam formation and its latitudinal distribution (Anguelova and Webster, 2006), by a process of quality control that excludes some residual cloud contamination (Zhang and Reid, 2010), by the accuracy of radiative transfer models used (Melin et al., 2010), and more accurate accounting for surface reflectance effects (Sayer et al., 2010).

A valid comparison among various models, satellite products and sunphotometer measurements (SP) is presented in Fig. 10. The frequency of occurrences histogram indicates that vast majority of the differences are positive. Only two out of nine differences (DA Terra-SP and AEROCOM-SP) are biased slightly negative. The AEROCOM-SP difference has a much wider distribution and as a consequence peaks at only $20 \%$, lower than others. GEOS-Chem is almost symmetrical around zero, although biased slightly high as are the other models and sensors. The MISR-SP distribution shows bi-modality mainly because of the small number of matchups available.

\section{Summary}

The Maritime Aerosol Network has continued extended spectral AOD data collection to areas that previously had no coverage. A web-based data archive provides the international scientific community with valuable data for satellite retrieval validation, atmospheric correction and other applications. Many areas of the World Ocean still have little or no coverage and our objective in the future is to extend 
coverage to all of these regions. Our international, multiinstitutional collaborative effort will significantly enhance our knowledge on the global aerosol distribution over the oceans. We foresee a continuation of this effort on various ships of opportunity.

Acknowledgements. The authors thank Hal Maring (NASA Headquarters) for his support of AERONET. The authors would like to acknowledge managerial and operational support from M. Sorokin, A. Scully, A. Tran, P. Kenny, D. Hamilton, L. Bariteau, R. Dunn, M. Conley, P. Schoessow, H. Gomes, L. Logan, M. Reynolds, A. Flores, D. A. Siegel, A. Proshutinsky, L. Rainville, A. Jayakumar, S. Schick, D. Menzies, E. Emry, C. Swan, K. G. Fairbarn (USA); M. Panchenko, O. Kopelevich, A. Sinitsyn, D. Kabanov, A. Tikhomirov, A. Kalsin, S. Terpugova, V. Polkin (Sr), V. Polkin (Jr), N. Vlasov, Y. Turchinovich, A. Gubin, Y. Zyulyaeva (Russia); P. Goloub, L. Blarel, S. Triquet, P. Hernandez, V. Duflot, T. Lecointre, S. Barataud, P. Ricaud, P. Sangiardi, A. Kartavtseff, J.-F. Ternon, F. Jourdin, C. Petus, J. Nicolas, S. Devidal, L. Martinon, M. Faillot, F. Gabarrot, N. Villeneuve, I. Jubert, M. Barblu, G. Duval (France); C. Powell, C. Gallienne (UK); C. Schlosser, Y. Zoll, M. Schlundt, M. Heller, T. Hanschmann, K. Lengfeld, A. Tessendorf, N. Renkosik, T. Heus, K. Lonitz, B. Quack, T. Dinter, A. Wassmann, M. Schlundt, B. Pospichal, F. Wittrock (Germany); A. Bromley, R. Martin, G. Brailsford (New Zealand); J. Kowalczyk, A. Ponczkowska, J. Pasnicki, K. Zielinski, P. Makuch, B. Lednicka (Poland); K. Niranjan, S. Babu, S. K. Satheesh, V. S. Nair, S. N. Beegum (India), S. Piketh, D. Williams, B. Kuyper, E. Robertson (South Africa), L. Jankowski, R. Matarrese (Italy), R. M. Castillo (Spain). One of the co-authors (Jean Sciare) would like to thank Institut Polaire Francais (IPEV) for the support provided within the AEROTRACE project.

Edited by: A. Kokhanovsky

\section{References}

Anguelova, M. D. and Webster, F.: Whitecap coverage from satellite measurements: A first step toward modeling the variability of oceanic whitecaps, J. Geophys. Res., 111, C03017, doi:10.1029/2005JC003158, 2006.

Barteneva, O. D., Nikitinskaya, N. I., Sakunov, G. G., and Veselova, L. K.: Atmospheric transmittance in the visible and near IR spectral range, Gidrometeoizdat, Leningrad, 224 pp., 1991.

Chin, M., Ginoux, P., Kinne, S., Holben, B. N., Duncan, B. N., Martin, R. V., Logan, J. A., Higurashi, A., and Nakajima, T.: Tropospheric aerosol optical thickness from the GOCART model and comparisons with satellite and sunphotometer measurements, J. Atmos. Sci., 59, 461-483, 2002.

Chin, M., Diehl, T., Dubovik, O., Eck, T. F., Holben, B. N., Sinyuk, A., and Streets, D. G.: Light absorption by pollution, dust, and biomass burning aerosols: a global model study and evaluation with AERONET measurements, Ann. Geophys., 27, 3439-3464, doi:10.5194/angeo-27-3439-2009, 2009.
Drury, E., Jacob, D. J., Spurr, R. J. D., Wang, J., Shinozuka, Y., Anderson, B. E., Clarke, A. D., Dibb, J., McNaughton, C., and Weber, R.: Synthesis of satellite (MODIS), aircraft (ICARTT), and surface (IMPROVE, EPA-AQS, AERONET) aerosol observations over eastern North America to improve MODIS aerosol retrievals and constrain aerosol concentrations and sources, J. Geophys. Res., 115, D14204, doi:10.1029/2009JD012629, 2010.

Eck, T. F., Holben, B. N., Reid, J. S., Dubovik, O., Smirnov, A., O'Neill, N. T., Slutsker, I., and Kinne, S.: Wavelength dependence of the optical depth of biomass burning, urban, and desert dust aerosol, J. Geophys. Res., 104, 31333-31350, 1999.

Haywood, J., Ramaswamy, V., and Soden, B.: Tropospheric aerosol climate forcing in clear-sky satellite observation over the oceans, Science, 283, 1299-1303, 1999.

Holben, B. N., Eck, T. F., Slutsker, I., Tanre, D., Buis, J. P., Setzer, A., Vermote, E., Reagan, J. A., Kaufman, Y., Nakajima, T., Lavenu, F., Jankowiak, I., and Smirnov, A.: AERONET - A federated instrument network and data archive for aerosol characterization, Remote Sens. Environ., 66, 1-16, 1998.

Holben, B. N., Tanre, D., Smirnov, A., Eck, T. F., Slutsker, I., Abuhassan, N., Newcomb, W. W., Schafer, J., Chatenet, B., Lavenue, F., Kaufman, Y. J., Van de Castle, J., Setzer, A., Markham, B., Clark, D., Frouin, R., Halthore, R., Karnieli, A., O’Neill, N. T., Pietras, C., Pinker, R. T., Voss, K., and Zibordi, Z.: An emerging ground-based aerosol climatology: Aerosol optical depth from AERONET, J. Geophys. Res., 106, 12067-12097, 2001.

Ichoku, C., Kaufman, Y. J., Remer, L. A., and Levy, R.: Global aerosol remote sensing from MODIS, Adv. Space Res., 34, 820827, 2004.

Jaeglé, L., Quinn, P. K., Bates, T., Alexander, B., and Lin, J.-T.: Global distribution of sea salt aerosols: new constraints from in situ and remote sensing observations, Atmos. Chem. Phys. Discuss., 10, 25687-25742, doi:10.5194/acpd-10-25687-2010, 2010.

Kahn, R. A., Gaitley, B., Martonchik, J., Diner, D., Crean, K., and Holben, B.: MISR global aerosol optical depth validation based on two years of coincident AERONET observations, J. Geophys. Res., 110, D10S04, doi:10.1029/2004JD004706, 2005..

Kahn, R. A., Garay, M. J., Nelson, D. L., Yau, K. K., Bull, M. A., Gaitley, B. J., Martonchik, J. V., and Levy, R. C.: Satellite-derived aerosol optical depth over dark water from MISR and MODIS: Comparisons with AERONET and implications for climatological studies, J. Geophys. Res., 112, D18205, doi:10.1029/2006JD008175, 2007.

Kahn, R. A., Gaitley, B. J., Garay, M., Diner, D. J., Eck, T. F., Smirnov, A., and Holben, B. N.: Multiangle Imaging SpectroRadiometer global aerosol product assessment by comparison with the Aerosol Robotic Network, J. Geophys. Res., 115, D23209, doi:10.1029/2010JD014601, 2010.

Kinne, S., Schulz, M., Textor, C., Guibert, S., Balkanski, Y., Bauer, S. E., Berntsen, T., Berglen, T. F., Boucher, O., Chin, M., Collins, W., Dentener, F., Diehl, T., Easter, R., Feichter, J., Fillmore, D., Ghan, S., Ginoux, P., Gong, S., Grini, A., Hendricks, J., Herzog, M., Horowitz, L., Isaksen, I., Iversen, T., Kirkevåg, A., Kloster, S., Koch, D., Kristjansson, J. E., Krol, M., Lauer, A., Lamarque, J. F., Lesins, G., Liu, X., Lohmann, U., Montanaro, V., Myhre, G., Penner, J., Pitari, G., Reddy, S., Seland, O., Stier, P., Takemura, T., and Tie, X.: An AeroCom initial assessment - optical properties in aerosol component modules of global models, 
Atmos. Chem. Phys., 6, 1815-1834, doi:10.5194/acp-6-18152006, 2006.

Kleidman, R. G., Smirnov, A., Levy, R. C., Mattoo, S., and Tanre, D.: Evaluation and wind speed dependence of MODIS aerosol retrievals over open ocean, IEEE T. Geosci. Remote, submitted, 2010.

Knobelspiesse, K. D., Pietras, C., and Fargion, F. S.: Sun-pointing error correction for sea deployment of the Microtops II handheld Sun photometer, J. Atmos. Ocean. Tech., 20, 767-771, 2003.

Knobelspiesse, K. D., Pietras, C., Fargion, G. S., Wang, M. H., Frouin, R., Miller, M. A., Subramaniam, S., and Balch, W. M.: Maritime aerosol optical thickness measured by handheld sunphotometers, Remote Sens. Environ., 93, 87-106, 2004.

Kopke, P., Hess, M., Schult, I., and Shettle, E. P.: Global aerosol data set, Max Planck Inst. fur Meteorol., Hamburg, Germany, 44 pp., 1997.

Lewis, E. R. and Schwartz, S. E.: Sea salt aerosol production: Mechanisms, methods, measurements, and models - A critical review, American Geophysical Union, Washington, DC, 413 pp., 2004.

Mahowald, N. M., Lamarque, J.-F., Tie, X. X., and Wolff, E.: Seasalt aerosol response to climate change: Last Glacial Maximum, pre-industrial and doubled carbon dioxide climates, J. Geophys. Res., 111, D05303, doi:10.1029/2005JD006459, 2006.

Melin, F., Clerici, M., Zibordi, G., Holben, B. N., and Smirnov, A.: Validation of SeaWiFS and MODIS aerosol products with globally distributed AERONET data, Remote Sens. Environ., 114, 230-250, 2010.

Moorthy, K. K., Beegum, S. N., Babu, S. S., Smirnov, A., John, S. R., Kumar, K. R., Narasimhulu, K., Dutt, C. B. S., and Nair, V. S.: Optical and physical characteristics of Bay of Bengal aerosols during W-ICARB: Spatial and vertical heterogeneities in the marine atmospheric boundary layer and in the vertical column, J. Geophys. Res., 115, D24213, doi:10.1029/2010JD014094, 2010.

Morys, M., Mims, F. M., Hagerup, S., Anderson, S. E., Baker, A., Kia, J., and Walkup, T.: Design, calibration, and performance of MICROTOPS II handheld ozone monitor and Sun photometer, J. Geophys.Res., 106, 14573-14582, 2001.

O'Dowd, C. D., Lowe, J. A., and Smith, M. H.: Coupling seasalt and sulphate interactions and its impact pn cloud droplet concentration predications, Geophys. Res. Lett., 26, 1311-1314, doi:10.1029/1999GL900231, 1999.

O’Neill, N. T., Eck, T. F., Holben, B. N., Smirnov, A., Dubovik, O., and Royer, A.: Bimodal size distribution influences on the variation of Angstrom derivatives in spectral and optical depth space, J. Geophys. Res., 106, 9787-9806, 2001.

O’Neill, N. T., Eck, T. F., Smirnov, A., Holben, B. N., and Thulasiraman, S.: Spectral discrimination of coarse and fine mode optical deph, J. Geophys. Res., 108(D17), 4559, doi:10.1029/2002JD002975, 2003.

Porter, J. N., Miller, M., Pietras, C., and Motell, G.: Ship-based sunphotometer measurements using Microtops sunphotometers, J. Atmos. Ocean. Tech., 18, 765-774, 2001.

Remer, L. A., Kleidman, R. G., Levy, R. C., Kaufman, Y. J., Tanre, D., Matoo, S., Martins, J. V., Ichoku, C., Koren, I., Yu, H. B., and Holben, B. N.: Global aerosol climatology from the MODIS satellite sensors, J. Geophys. Res., 113, D14S07, doi:10.1029/2007JD009661, 2008.
Sayer, A. M., Thomas, G. E., and Grainger, R. G.: A sea surface reflectance model for (A)ATSR, and application to aerosol retrievals, Atmos. Meas. Tech., 3, 813-838, doi:10.5194/amt-3813-2010, 2010.

Schulz, M., Textor, C., Kinne, S., Balkanski, Y., Bauer, S., Berntsen, T., Berglen, T., Boucher, O., Dentener, F., Guibert, S., Isaksen, I. S. A., Iversen, T., Koch, D., Kirkevåg, A., Liu, X., Montanaro, V., Myhre, G., Penner, J. E., Pitari, G., Reddy, S., Seland, Ø., Stier, P., and Takemura, T.: Radiative forcing by aerosols as derived from the AeroCom present-day and pre-industrial simulations, Atmos. Chem. Phys., 6, 5225-5246, doi:10.5194/acp-6-5225-2006, 2006.

Shi, Y., Zhang, J., Reid, J. S., Holben, B., Hyer, E. J., and Curtis, C.: An analysis of the collection 5 MODIS over-ocean aerosol optical depth product for its implication in aerosol assimilation, Atmos. Chem. Phys., 11, 557-565, doi:10.5194/acp-11-557-2011, 2011.

Smirnov, A., Holben, B. N., Kaufman, Y. J., Dubovik, O., Eck, T. F., Slutsker, I., Pietras, C., and Halthore, R.: Optical properties of atmospheric aerosol in maritime environments, J. Atmos. Sci., 59, 501-523, 2002.

Smirnov, A., Holben, B. N., Lyapustin, A., Slutsker, I., and Eck, T. F.: AERONET processing algorithm refinement, AERONET Workshop, El Arenosillo, Spain, 10-14 May, 2004.

Smirnov, A., Holben, B. N., Sakerin, S. M., Kabanov, D. M., Slutsker, I., Chin, M., Diehl, T. L., Remer, L. A., Kahn, R. A., Ignatov, A., Liu, L., Mishchenko, M., Eck, T. F., Kucsera, T. L., Giles, D. M., and Kopelevich, O. V.: Ship-based aerosol optical depth measurements in the Atlantic Ocean, comparison with satellite retrievals and GOCART model, Geophys. Res. Lett., 33, L14817, doi:10.1029/2006GL026051, 2006.

Smirnov, A., Holben, B. N., Slutsker, I., Giles, D. M., McClain, C. R., Eck, T. F., Sakerin, S. M., Macke, A., Croot, P., Zibordi, G., Quinn, P. K., Sciare, J., Kinne, S., Harvey, M., Smyth, T. J., Piketh, S., Zielinski, T., Proshutinsky, A., Goes, J. I., Nelson, N. B., Larouche, P., Radionov, V. F., Goloub, P., Moorthy, K. K., Matarrese, R., Robertson, E. J., and Jourdin, F.: Maritime Aerosol Network as a component of Aerosol Robotic Network, J. Geophys. Res., 114, D06204, doi:10.1029/2008JD011257, 2009.

Textor, C., Schulz, M., Guibert, S., Kinne, S., Balkanski, Y., Bauer, S., Berntsen, T., Berglen, T., Boucher, O., Chin, M., Dentener, F., Diehl, T., Easter, R., Feichter, H., Fillmore, D., Ghan, S., Ginoux, P., Gong, S., Grini, A., Hendricks, J., Horowitz, L., Huang, P., Isaksen, I., Iversen, I., Kloster, S., Koch, D., Kirkevåg, A., Kristjansson, J. E., Krol, M., Lauer, A., Lamarque, J. F., Liu, X., Montanaro, V., Myhre, G., Penner, J., Pitari, G., Reddy, S., Seland, Ø., Stier, P., Takemura, T., and Tie, X.: Analysis and quantification of the diversities of aerosol life cycles within AeroCom, Atmos. Chem. Phys., 6, 1777-1813, doi:10.5194/acp-61777-2006, 2006.

Tomasi, C., Vitale, V., Lupi, A., Di Carmine, C., Campanelli, M., Herber, A., Treffeisen, R., Stone, R. S., Andrews, E., Sharma, S., Radionov, V., von Hoyningen-Huene, W., Stebel, K., Hansen, G. H., Myhre, C. L., Wehrli, C., Aaltonen, V., Lihavainen, H., Virkkula, A., Hillamo, R., Strom, J., Toledano, C., Cachorro, V. E., Ortiz, P., de Frutos, A. M., Blindheim, S., Frioud, M., Gausa, M., Zielinski, T., Petelski, T., and Yamanouchi, T.: Aerosols in polar regions: A historical overview based on optical depth and in situ observations, J. Geophys. Res., 112, D16205, 
doi:10.1029/2007JD008432, 2007.

Vinoj, V., Anjan, A., Sudhakar, M., Satheesh, S. K., Srinivasan, J., and Moorthy, K. K.: Latitudinal variation of aerosol optical depths from northern Arabian Sea to Antarctica, Geophys. Res. Lett., 34, L10807, doi:10.1029/2007GL029419, 2007.

Zhang, J. and Reid, J. S.: MODIS Aerosol product analysis for data assimilation: Assessment of Level 2 aerosol optical thickness retrievals, J. Geophys. Res., 111, D22207, doi:10.1029/2005JD006898, 2006.
Zhang, J. and Reid, J. S.: A decadal regional and global trend analysis of the aerosol optical depth using a data-assimilation grade over-water MODIS and Level 2 MISR aerosol products, Atmos. Chem. Phys., 10, 10949-10963, doi:10.5194/acp-1010949-2010, 2010. 